\title{
ARTICLE
}

\section{PROBABILISTIC SEISMIC HAZARD ASSESSMENT FOR BAYANKHONGOR AIMAG OF MONGOLIA}

\author{
Ankhtsetseg D., Odonbaatar Ch. *, Mongonsuren D., Bayarsaikhan E. and Dembereldulam M.
}

Department of Seismology, Institute of Astronomy \& Geophysics Mongolian Academy of Sciences, Ulaanbaatar, Mongolia

\begin{abstract}
Central Asia is one of the seismically most active regions in the world. Its complex seismicity is due to the collision of the Eurasian and Indian plates, which has resulted in some of the world's largest intraplate events over history. The region is dominated by reverse faulting over strike slip and normal faulting events.The GSHAP project, aiming at hazard assessment on a global scale, indicates that the territory of Bayankhongor aimag, Mongolia, in Central Asia is characterized by maximum bedrock peak ground accelerations for $10 \%$ probability of exceedance in 50 years as medium as in range of 80 to $160 \mathrm{~cm} / \mathrm{s}^{2}$. In this study, which has been carried out within the framework of the project "Seismic microzoning map of center of 12 aimags, Mongolia", the area source model and different kernel approaches are used for a probabilistic seismic hazard assessment for the Mongolia. The seismic hazard is assessed considering shallow (depth $<50$ $\mathrm{km}$ ) seismicity only and employs an updated (with respect to previous projects) earthquake catalogue for the region. The hazard maps, shown in terms of $10 \%$ probability of exceedance in 50 years, are derived by using the Open Deterministic and Probabilistic Seismic Hazard Assessment (ODPSHA), which is based on the Cornell methodology. The maximum hazard observed in the region reaches $93-98 \mathrm{~cm} / \mathrm{s}^{2}$, which in intensity corresponds to VII in MSK64 scale in the centre of Bayankhongor aimag for 475 years mean return period.
\end{abstract}

Keywords: seismicity; seismic hazard analysis; hazard curve; peak ground acceleration;

\section{INTRODUCTION}

Central Asia is a region with a high level of seismic hazard. Unlike earthquakes that occur along plate boundaries, continental earthquakes are widely distributed over large regions and typically have shallow depths, in the range of 10 to $25 \mathrm{~km}$ beneath the surface. Major continental earthquakes usually occur along seismically active faults, which individually have very long recurrence intervals (in the range of several thousand years). Late Quaternary deformation in Mongolia is distributed over a vast region, and includes a full spectrum of deformation styles and structural orientations. Much of the deformation in western Mongolia can be attributed to the collision and subsequent penetration of the Indian plate with respect to Eurasia. In northern Mongolia, there is an 
influence of extensional tectonics related to the active Baikal rift system. The occurrence and distribution of strong earthquakes are the manifestation and result of these widespread and varied styles of deformation. The locations of earthquakes, especially large earthquakes are not uniformly and randomly distributed rather they cluster on several faults and blocks of prominent late Quaternary tectonic activity.

The assessment of seismic hazard depends upon our understanding of how earthquakes are generated and distributed and how they recur in space and time. There are different approaches commonly used in probabilistic seismic hazard analysis (PSHA) at regional scale. For a country like Mongolia with poor historical and short instrumental records, as well as with very long recurrence intervals, seismotectonic methods seem to be the most appropriate. The seismotectonic approach incorporates geological and seismological evidence to supplement the historical record of seismicity. The fundamental level uses geodynamic information to identify potential source areas and to delineate regions of comparable tectonic activity over which all available information can be averaged. More advanced approaches incorporate fault locations and rates, by gauging crustal deformation through geomorphology and space geodesy, and average recurrence intervals by analysing records of individual paleo-earthquakes.

During the past few years, the availability of records of individual paleo-earthquakes and reliable indicators of the long term activity of large active faults has provided key input to extend the historical record to cover recurrence times of 100 to 100,000 years. These accomplishments (made possible by the results of new disciplines such as paleoseismology, geomorphology, geochronology, remote sensing and space geodesy) resulted in substantial improvements in the identification of seismic source regions adopted in traditional seismotectonic for Seismic Hazard Analysis (SHA). An active fault of interest for SHA is a structure that has an established record of activity in Late Pleistocene (i.e. in the past 125 ka) and demonstrable or inferable capability of generating major earthquakes. The purpose of this study is to report the results of PSHA conducted on adequate database at the Institute of Astronomy and Geophysics, Mongolian Academy of Sciences (IAG, MAS) under the framework of a project called "Seismic microzoning map of centre of 12 aimags" funded by the Ministry of Construction and Urban Development of Mongolia for providing important standard parameters for Mongolia's Building Code [21].

The study area, Bayankhongor aimag, is located in the Gobi-Altay seismic active zone $(12 / 04 / 1957, \mathrm{Mw}=8.3)$ in the central zone of Mongolia. In the Gobi-Altay range, the main activity is associated left-lateral strike slip with the Bogd earthquake, (12/04/1957, $\mathrm{Mw}=8$, epicentral intensity XI-XII) and its aftershocks. Its fault surface rupture is 270 $\mathrm{km}$ [4]. In the seismic hazard calculation, we should assess potential seismic active zones with active faults: Bogd, Western Bogd, Bayankhongor, Otgon, Bayanbulag, and Egiin Davaa surrounding of Bayankhongor aimag. The most used PSHA methodology associates a probability (usually converted in return period) for a given acceleration at the site. It allows to define the recurrence time between the events and consider building protection for public safety and welfare. The impact of the most unfavourable event, called "scenario", in term of ground acceleration, is a target of result of seismic hazard study. We analysed the PSHA of Bayankhongor aimag using a recent methodology of logic tree in seismicity and active faults' characteristic. The acceleration levels are with 475, 975, 2475 year return periods at class B (Rock) sites. 


\section{MATERIALS AND METHODS}

Seismic zoning map of Mongolia, 1985: Over past several decades, Russian and Mongolian Academy of Sciences have collaborated under the framework of seismology and active deformation. Several books and papers were published on the subject, with the publication of a compilation of their joint common work in 2004. From this common work, and using other recent work [4, 5, 25], Klyuchevskii et al. (2004) a map of Mongolia titled "Possible Location and Intensity of Potential Seismic Shocks" [15] was proposed. It corresponds to the deterministic approach of seismicity using mainly the observed intensity. This seismic zoning in Mongolia was performed using "Seismic zoning map of Mongolia, 1985" (Figure 1), and the 1996 map of "Zones of occurrence of earthquake in Siberia and Mongolia" which is a statistical zoning of observed earthquakes with a magnitude of more than 6.5 [16]. Indeed, they used not only the faults, which were associated to known events, but also a model of large active faults that has been detected on the field [14] or satellite images by different studies.

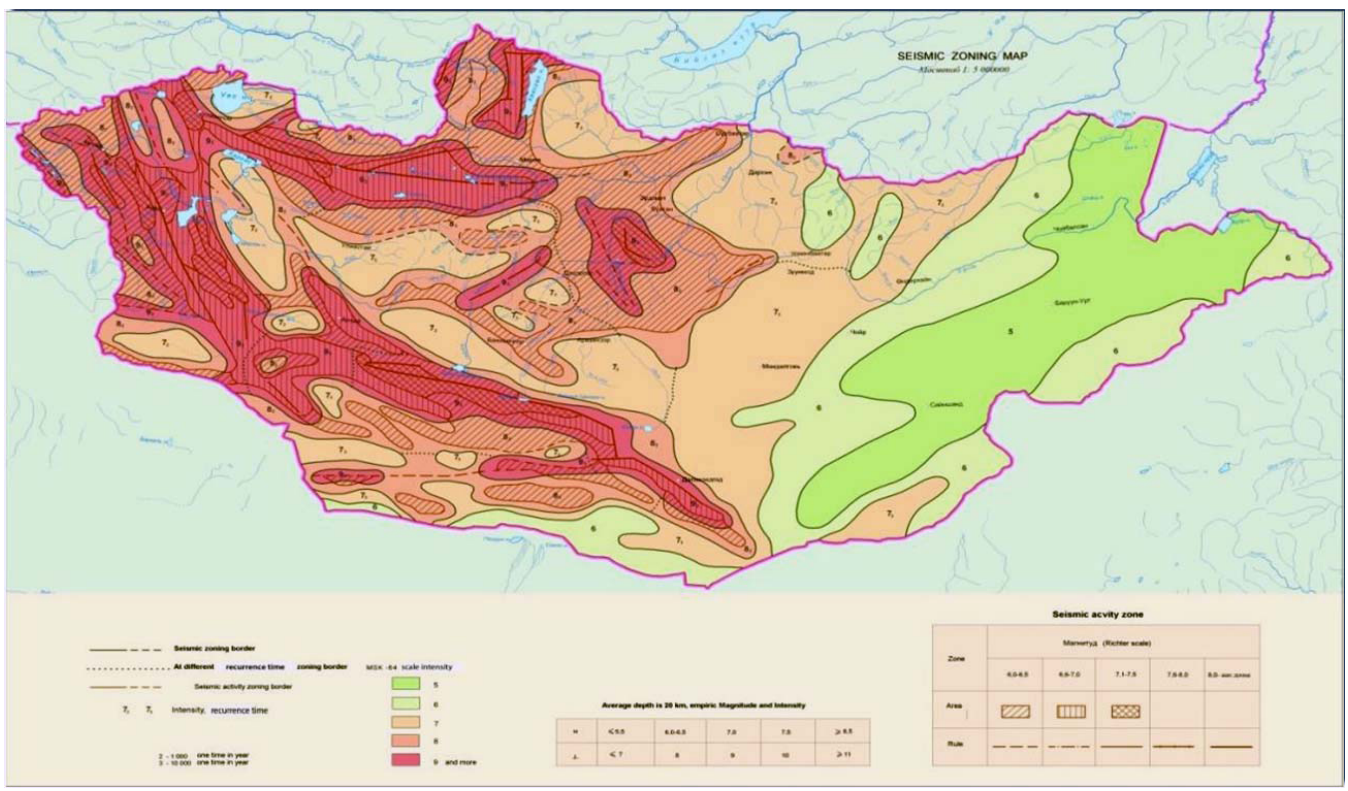

Figure 1. The seismic zoning map of Mongolia, 1985

The technique they used for this seismic zoning is based on the determination of the average radius of isoseists (interpreted from macroseismic investigations after strong earthquakes) of the largest earthquakes that occurred in Mongolia. They consider events of magnitude 6.5 to 8 placed along the main faults and consider the zones seismically homogeneous. The result is a deterministic map (they consider the largest event possible deduced from their seismotectonic model) with a scale in Intensity (MSK 64). By this map, the centre of Bayankhongor aimag appertains to the intensity zone of VIII with a probability of one event occurring in 10,000 years [14].

GSHAP (Global Seismic Hazard Assessment Program): has the aim to produce a world map of seismic hazard deduced from a PSHA [12]. Despite the scale of their work, the aim of their map is not appropriate for use for a specific site or a city, but it is the result of a probabilistic approach using world seismic 
data and simple parameters. This hazard map represents the probabilistic maximum bedrock acceleration with a $10 \%$ probability of exceedance in 50 years, corresponding to a return period of 475 years. For Bayankhongor aimag, the maximum bedrock acceleration determined from this hazard is in the range 80 to $160 \mathrm{~cm} / \mathrm{s}^{2}$ (intensity of VII-VIII) (Figure 2). This world compilation (GSHAP) of seismic hazard map of Mongolia must be used for general case.

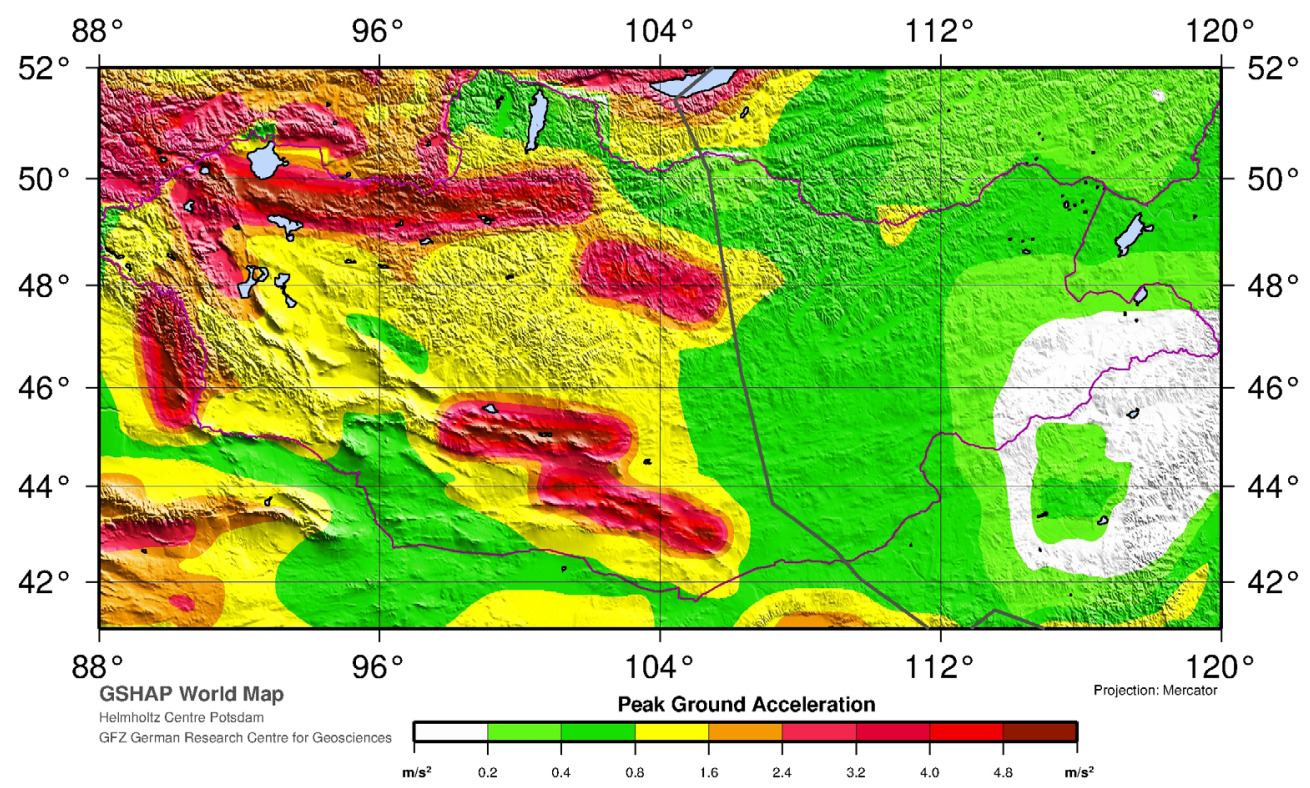

Figure 2. Seismic hazard map of Mongolia by GSHAP hazard calculation

Seismic Hazard Analysis approach: In both approaches it is assumed that seismicity can be represented from a seismotectonic model that consists of polygonal zones and faults, with appropriate characteristics. This model is often referred to as "the seismotectonic zonation". In a deterministic approach, only one single scenario is used, chosen from all its various possibilities, usually the most unfavourable one. Each zone or fault is then characterised by a unique maximum plausible earthquake, which is assumed to have an evenly distributed spatial probability of occurrence. Once the reference scenario is chosen, and provided that attenuation laws and site effects are known, such an approach allows estimating the (maximum) expected ground motions at any point. The resulting map is then very sensitive to any change in the geometry of the seismotectonic model or of the magnitude of the maximum plausible earthquakes, as well as to any reappraisal of site's effects or attenuation laws. Moreover, uncertainties on the various parameters are usually incorporated by considering systematically the most conservative sets of parameters and fixed safety margins, yielding to probably unrealistic overestimations of hazard. Finally, the possibility that the ground motion may exceed the value obtained from a deterministic map cannot be easily quantified. In view of these shortcomings, probabilistic methods have been designed and have become increasingly popular. The probabilistic approach also requires a seismotectonic model, but the zones and faults are not characterised by a single maximum plausible earthquake. Polygonal zones are characterised by a frequency-magnitude distribution, generally assumed to fit the experimentally observed 
power-law distribution [13]. Faults are generally assumed to obey the characteristic fault model [27], which, although debated, seems a reasonable assumption for seismic hazard assessment [28].

PSHA methodology: We are no longer searching for an elusive worst-case ground motion intensity. Rather, we will consider all possible earthquake events and resulting ground motions, along with their associated probabilities of occurrence, in order to find the level of ground motion intensity exceeded with some tolerably low rate. At its most basic level, PSHA is composed of five steps [3]:

1. Identify all earthquake sources capable of producing damaging ground motions;

2. Characterise the distribution of earthquake magnitudes (the rates at which earthquakes of various magnitudes are expected to occur);

3. Characterise the distribution of sourceto-site distances associated with potential earthquakes;

$$
\lambda(a)=\sum_{\text {source }} v_{\text {source }} \times \iint_{(m, r) \in \text { source }} \mathrm{I}[P G A \geq a / m, r] f_{M}(m) f_{R}(r) d m d r
$$

where:

- $v_{\text {source }}$ is the annual activity rate (the mean annual rate of occurrence of events with magnitude greater than the detection threshold in the source considered);

- I $[P G A \geq a / m, r]$ is the indicator function for the predicted PGA of an earthquake of magnitude $\mathrm{m}$ and distance $\mathrm{r}$ from the site with respect to the level a;

- $f_{M}(m)$ and $f_{R}(r)$ are the probability density function of magnitude $M$ and distance $R$ respectively for the source considered.

Database: The work also takes advantage of very recent advances in the modelling of strong ground motion. The underlying earthquake catalogue is include historical events with minor unpublished revisions and extended up to the end of December 2015 in the database of Mongolian National Data Centre of IAG, MAS. All the magnitude values in this report can be taken to be moment magnitude (Mw)
4. Predict the resulting distribution of ground motion intensity as a function of earthquake magnitude, distance, etc;

5. Combine uncertainties in earthquake size, location and ground motion intensity, using a calculation known as the total probability theorem.

The end result of these calculations will be a full distribution of levels of ground shaking intensity, and their associated rates of exceedance. These results can then be used to identify a ground motion intensity having an acceptably small probability of being exceeded.

The standard PSHA integrates the mean annual rate of occurrence of earthquakes over all possible earthquakes, that means, over all possible locations and magnitudes in all potential seismic sources (faults and zones). Formally, the analytical expression of the mean annual frequency of exceedance acceleration level "a" at a given site is:

unless otherwise specified. This is in contrast to most of the literature on Mongolian seismicity, where local magnitude (ML) is generally used. Conversions from $\mathrm{Ml}$ to $\mathrm{Mw}$ have been made following Yenier E, Erdogan O, and Akkar S., 2008 [29]. In the seismic hazard calculation, we should consider seismotectonic model, potential seismic active zones and active faults. We analysed probabilistic analysis using a recent methodology of logic tree in seismic activity and earthquake probability, b value of seismicity analysis using RichterGutenberg ratio and active faults' parameters within a radius of $250 \mathrm{~km}$.

Characterization of seismic sources: It was considered in two different ways. Areas with well defined active fault were considered as fault buffer zones and maximum magnitude was defined by historic events, paleoseismic study results or simple relation with fault size. The widths of buffer zones were estimated 
by fault segments and seismicity. Minimum buffer width was defined as $5 \mathrm{~km}$ from the fault line. For non-active fault areas, we used source and its location as previously defined areas. [21]. Area source maximum magnitude were assumed as 6.5. For active fault zones until magnitude 6.5 used Gutenberg-Richter law and maximum magnitude recurrence were determined paleoseismic and historical data. For the calculation of probability of

\section{RESULTS AND DISCUSSION}

PSHA calculation: The interactive Seismic Hazard Analysis program, "Open Deterministic and Probabilistic Seismic Hazard Assessment" (ODPSHA), has been developed by Dr. Odonbaatar, a researcher of IAG, in MATLAB code. The ODPSHA software is based on the methodology of Cornell to construct probabilistic seismic hazard (PSH) map [11].The first version of the software has been tested for the specific area's seismic hazard determination and its results have been compared with international standard software. Following active fault main parameters were applied for the computation of seismic use: locations, sizes, tectonic types, and recurrence rates of earthquakes defined into a source model for estimating probabilistic seismic hazard for a gridwork of sites with a grid spacing of 0.01 degrees in latitude and longitude (about $1 \mathrm{~km}$ spacing). The acceleration levels are 475, 975, 2475 year return periods at class B (Rock) sites. In this the next maximum event we used logic tree. The final calculations were made for 20 active fault buffer zones and 3 seismic area source zones (Gobi-Altai, Khangai, Sharga) in Bayankhongor area (Figures 3 and 4). For hazard calculation, we input recurrence time as 6500 years for Bayankhongor fault and Nariin Teel fault and as 3500 years for Ikh Bogd fault system $[22,25]$.

paper, we have shown the seismic hazard map for 475 and 2475 year return periods only for building code requirement.

We determined the Peak Ground Acceleration (PGA) at each point in $1 \mathrm{~km}$ set of $116044 \mathrm{~km}^{2}$, in a total of 118270 points data created. We assumed boundary of study area as border of Bayankhongor aimag. This calculation includes both maximum magnitude Mmax $=6.5$ and minimum magnitude Mmin=4.0. Seismic ground motion prediction equation (GMPE) did not exist in the territory of Mongolia due to the lack of strong ground motion acceleration data. Therefore, we selected the most optimal existing GMPE using regression analysis based on relationship of MNDC acceleration data and international standard GMPE [22]. Consequently, Chandra 1979 equation was used for calculation [9].

The probability distribution functions of magnitude and distance for source to site are shown in Figures 3 and 4.

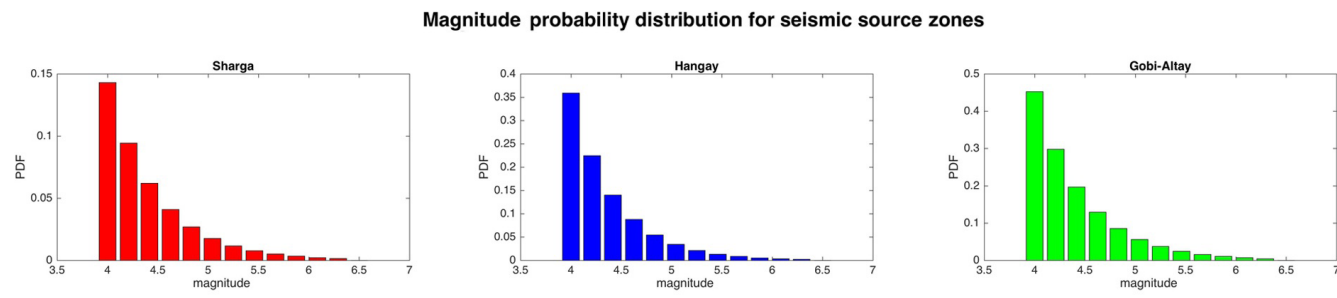

Figure 3. Probability Distribution Function (PDF) of magnitude for Khangai, Sharga and Gobi-Altay source zones with a truncated Gutenberg-Richter distribution, a minimum considered magnitude of 4, a maximum magnitude of 6.5 . 
DISTANCE probability distribution for seismic source zones
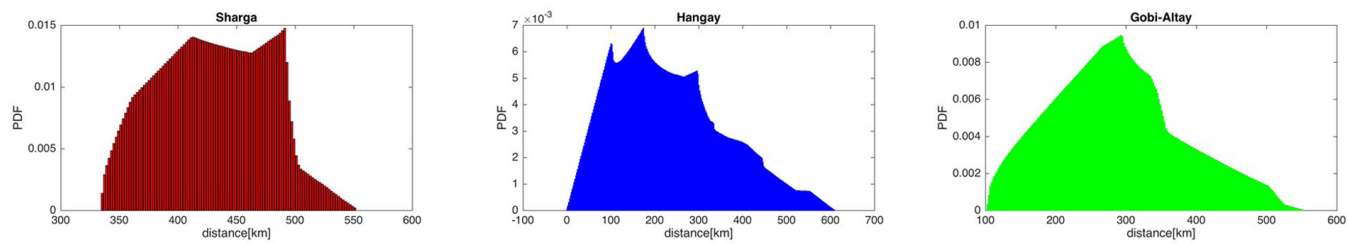

Figure 4. Probability distribution function of the source-to-site distance for potential earthquakes from the Sharga, Khangai and Gobi-Altay source zones

Within a radius of $250 \mathrm{~km}$ from the centre of Bayankhongor aimag, , there are 20 active fault zones. Probability density functions of magnitude $M$ and distance $R$ respectively for these active fault sources are shown in the Figures 5 and 6. 
Magnitude probability distribution for seismic source zones
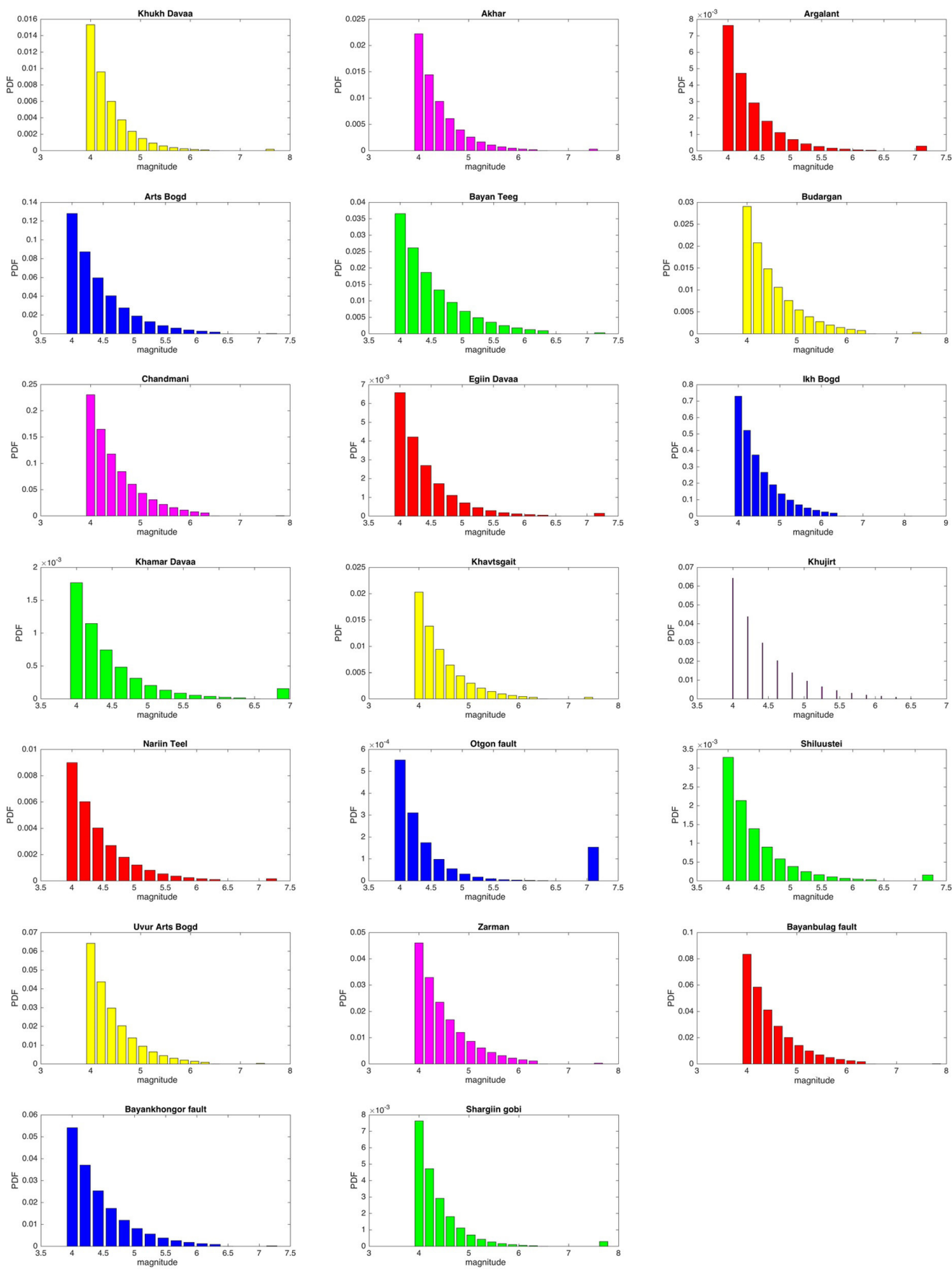

Figure 5. Probability distribution function of magnitude for an active fault source, a minimum considered magnitude of 4 , a maximum magnitude of 6.5 with parameters of seismicity analysis 
DISTANCE probability distribution for seismic source zones
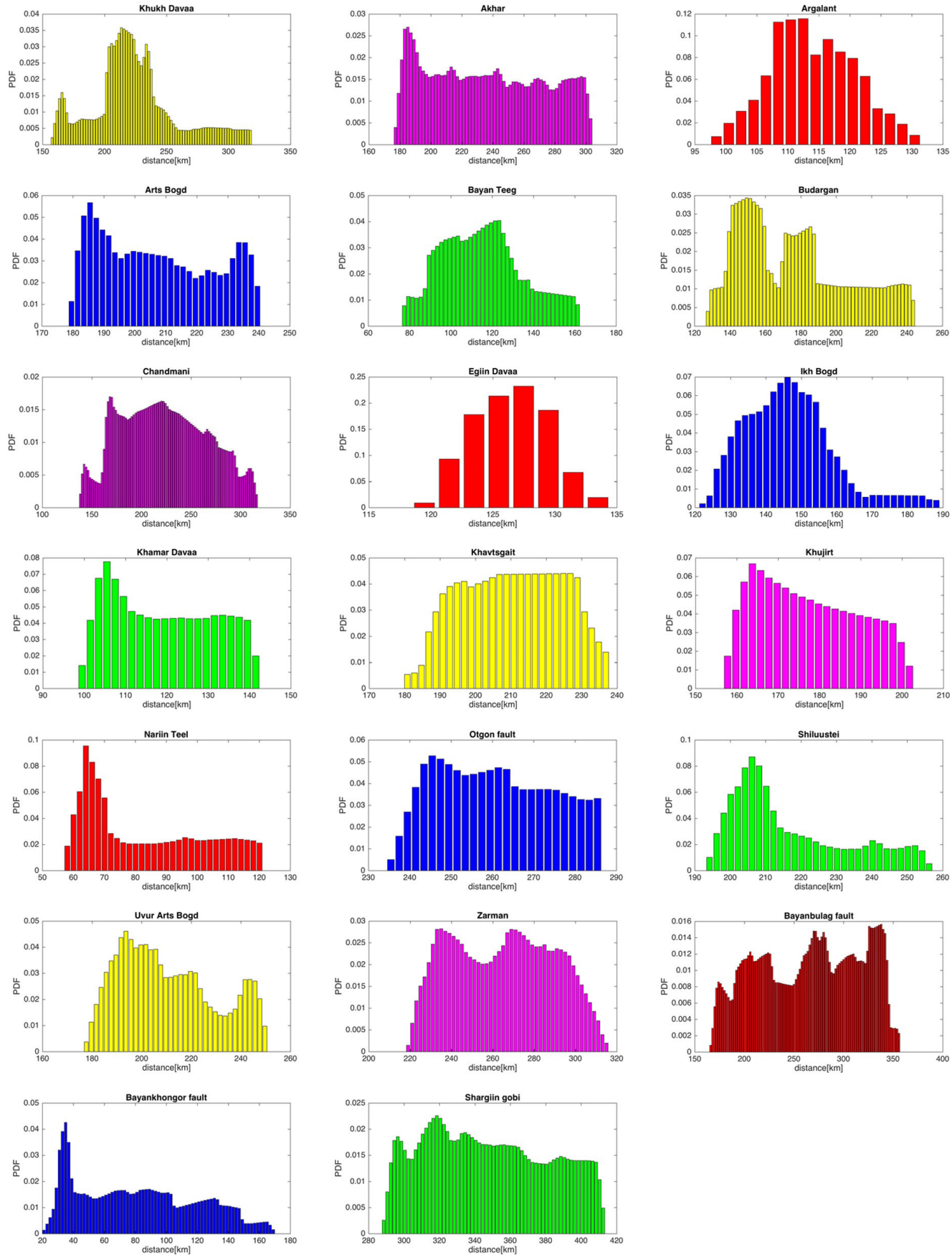

Figure 6. Probability distribution function of the source-to-site distance for potential earthquakes from the 20 active fault zones 
Probabilistic seismic hazard curve for Bayankhongor aimag in PGA (at rock): Maximum ground motion on bedrock for return periods of 475 and 975 years.

We calculated newly created combination geological data describing the geometry and seismic activity of 20 major active fault zones (locations, fault lengths, fault type, slip

\section{Seismic hazard curve: BAYANKHONGOR CENTER}

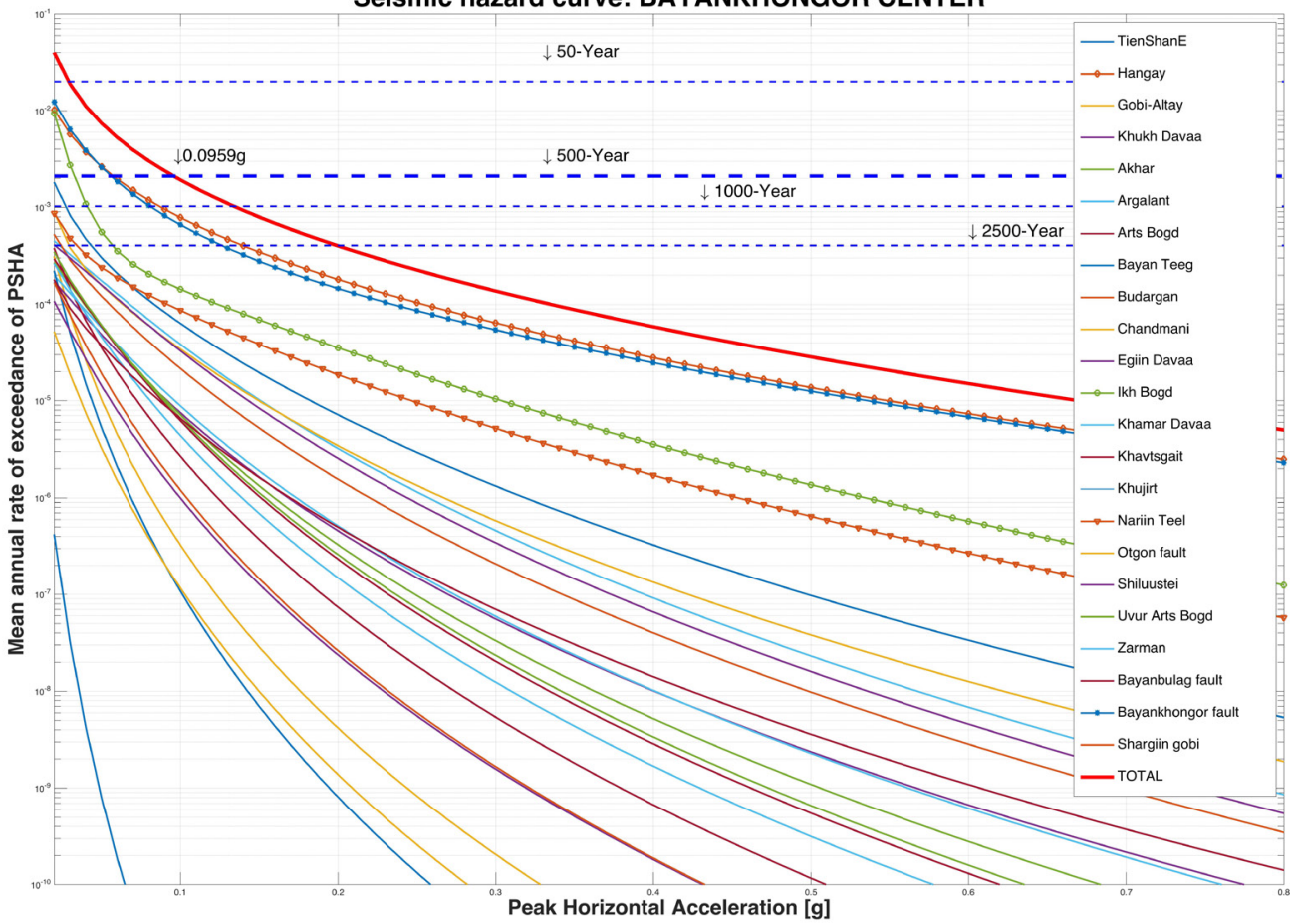

Figure 7. The probabilistic seismic hazard curve for Bayankhongor aimag in PGA (at rock)

Figure 7 shows the probabilistic seismic hazard curves for Bayankhongor aimag in PGA (peak ground acceleration) according to our model. These curves are calculated at the rock site and the distances considered are relative to the center of Bayankhongor aimag, Mongolia. In the seismic hazard curve, dashed blue lines, correspond to exceedance probability in 475,975 , and 2475 years. The return period of 475-years uses into recent validated building code of Mongolia. The PGA at 475-years return period reaches $93-98 \mathrm{~cm} /$ $\mathrm{s}^{2}$ (Intensity of VII) at the rock site of centre of Bayankhongor aimag, which is considered rates, single event displacements, estimated magnitudes, and average recurrence intervals), and combined them with historical seismicity data to develop Seismic Hazard Mapping for the study area (Figure 7). The maximum magnitude and return period for active faults were selected from existing paleoseismic data [14]. 
Table 1. The summarised PSHA for Bayankhongor aimag

\begin{tabular}{|c|c|c|}
\hline Return period (year) & PGA $\left(\mathrm{cm} / \mathrm{s}^{2}\right)$ & $\begin{array}{c}\text { Corresponding MSK64 } \\
\text { Intensity }\end{array}$ \\
\hline 475 & $93-98$ & VII \\
\hline 975 & $130-136$ & VII \\
\hline 2475 & $193-201$ & VIII \\
\hline 4975 & $254-265$ & VIII \\
\hline
\end{tabular}

Seismic hazard map: The contribution of each source for the return period of 475 and 2475 years at the centre of Bayankhongor aimag was determined from seismic hazard curves (Figure 8). The meaning of 93-98 cm/ $\mathrm{s}^{2}$ for 475 years return period is earthquake peak ground acceleration (PGA) that has a $10 \%$ chance of being exceeded in 50 years and 2475 return period is earthquake peak ground acceleration (PGA) that has a $2 \%$ chance of being exceeded in 50 years.
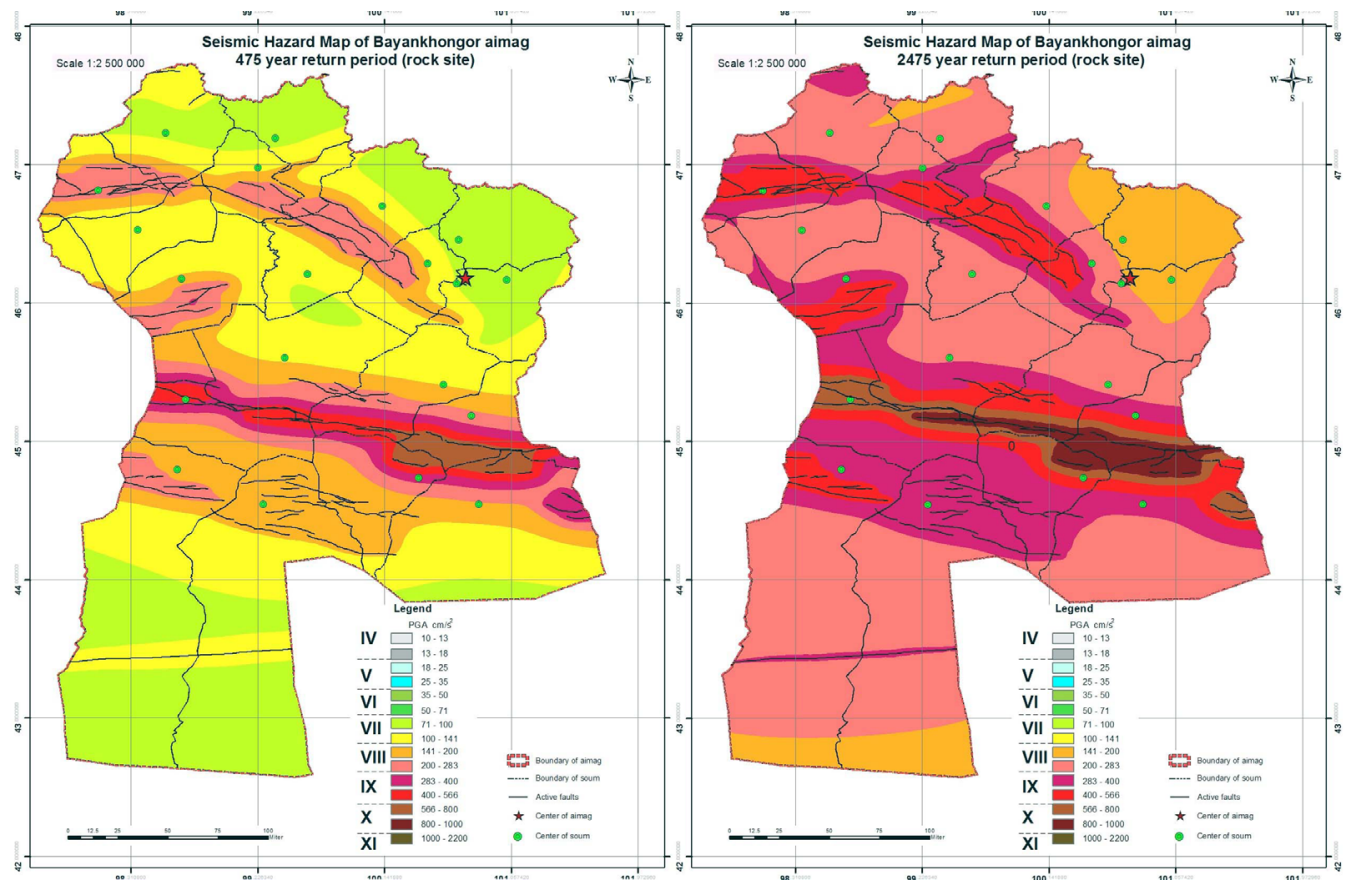

Figure 8. Seismic hazard map of Bayankhongor aimag, Mongolia. Red star-centre of aimag

From the seismic hazard map, the percentage of coverage area for each pertained intensity zones used for calculating return periods is shown in the Table 2 . 
Table 2. The intensity pertained area for Bayankhongor aimag

\begin{tabular}{|c|c|c|c|c|c|c|}
\hline $\mathrm{N}$ & $\begin{array}{c}\text { Return period } \\
\text { (year) }\end{array}$ & $\begin{array}{c}\text { Zone - VII } \\
(\%)\end{array}$ & $\begin{array}{c}\text { Zone - VIII } \\
(\%)\end{array}$ & $\begin{array}{c}\text { Zone - IX } \\
(\%)\end{array}$ & $\begin{array}{c}\text { Zone - X } \\
(\%)\end{array}$ & $\begin{array}{c}\text { Zone - XI } \\
(\%)\end{array}$ \\
\hline 1 & 475 & 62.2 & 29.6 & 6.4 & 1.8 & - \\
\hline 2 & 975 & 23.4 & 59.4 & 14 & 3.2 & - \\
\hline 3 & 2475 & - & 60.1 & 33.5 & 6.4 & - \\
\hline 4 & 4975 & - & 19.9 & 66.2 & 13.9 & - \\
\hline
\end{tabular}

\section{CONCLUSIONS}

The PGA at 475-years return period reaches $93-98 \mathrm{~cm} / \mathrm{s}^{2}$ (Intensity of VII) at the rock site of centre of Bayankhongor aimag, which is considered to be a high hazard (very strong perceived shaking with maximum potential damage) zone. For 2475-years return period, PGA reaches 193-201 cm/ $/ \mathrm{s}^{2}$. We considered possible associated intensity of VII to VIII in the MSK64 scale. For potential seismic event, at the centre of Bayankhongor aimag, the minimum protection should be $93-98 \mathrm{~cm} / \mathrm{s}^{2}$ or intensity VII for the 475-years return period.

Acknowledgments: We thank all members of the Department of Seismology, IAG MAS for their generous contribution. Our special thanks to all members of the laboratory of seismic hazard assessment for their hard work and patience. We thank all colleagues of IAG MAS for their invaluable support. We thank "anonymous" reviewers for their so-called insights. We thank Professor Dr. Dinil Pushpalal, Department of International Environment and Resources Policy, Graduate School of International Cultural Studies, Tohoku University for his peer review of an old edition of the manuscript. This work has been executed with the financial support from the Ministry of Construction and Urban Development of Mongolia.

\section{REFERENCES}

[1] Abrahamson, N. A., and W. J. Silva., 1997. "Empirical Response Spectral Attenuation Relations for Shallow Crustal Earthquakes", Seismological Research Letters, Vol. 68, No. 1, pp. 94-127.

[2] Ambraseys, N. N., K. A. Simpson and J. J. Bommer, 1996, "Prediction of Horizontal Response Spectra in Europe", Earthquake Engineering and Structural Dynamics, Vol. 25, pp. 371-400.

[3] Baker, J. W., 2008, An Introduction to Probabilistic Seismic. Hazard Analysis (PSHA).

[4] Baljinnyam, I., Bayasgalan, A., Borisov, B. A., Cisternas, A., Dem'yanovich, M.G., Ganbaatar, L., Kochetkov, V. M., Kurushin, R. A., Molnar, P., Philip, H., and Vashchilov, Y. Y., 1993, Ruptures of Major Earthquakes and Active Deformation in Mongolia and its Surroundings, Geological Society of America MemoirE 18, pp. 1-16.

[5] Bayasgalan. A., 1999, Active Tectonics of Mongolia, Ph.D thesis, University of Cambridge, Cambridge, p. 182.

[6] Bayasgalan, A., and J. A. Jackson., 1999. A Re-Assessment of the Faulting in the 1967 Mogod Earthquakes in Mongolia, Geophys. J. Int. 138, pp. 784-800.

[7] Bayasgalan, A., James Jackson., Dan McKenzie, 2000, Earthquake Source Parameters, Seismogenic Thickness and Effective Elastic Thickness in Mongolia, Geophys. J. Int.

[8] Calais, E., and Amarjargal, S., 2000. New Constraints on Current Deformation in Asia from Continuous GPS Measurements at Ulaanbaatar, Mongolia, Geophys. Res. Lett., 27, pp. 1527-1531.

[9] Chandra, U., 1979. "Attenuation of Intensities in the United States Bulletin of the Seismological 
Society of America", Vol. 69, No. 6, pp. 2003-2024.

[10] Chen, L., Faccioli E., 2008. "Ground Motion Attenuation Relationships based on Chinese and Japanese Strong Ground Motion Data" European School for Advanced Studies - Reduction of Seismic Risk, Rose University.

[11] Cornell, C. A., 1968, Engineering Seismic Risk Analysis, Bull. Seism. Soc. Am. 58, pp. 1583-1606.

[12] Giardini, D., G. Grünthal, K. Shedlock, and P. Zhang, (1999) GLOBAL SEISMIC HAZARD MAP Produced by the Global Seismic Hazard Assessment Programme (GSHAP), a demonstration project of the UN/International Decade of Natural Disaster Reduction, conducted by the International Lithosphere Programme. Global map assembled by D. Giardini, G. Grünthal, K. Shedlock, and P. Zhang.

[13] Gutenberg, B., et C.F. Richter, (1956). Earthquake Magnitude, Intensity, Energy and Acceleration, Bull. Seism. Soc. Am. 46, pp. 105-145.

[14] Khilko, S. D., R. A. Kurushin, V. M. Kochetkov, L. A. Misharina, V .I. Melnikova, N. A. Gilyova, S. V. Lastochkin and D. Mönhöö., 1985. Earthquakes and the Base of the Seismic Zoning of Mongolia. Vol. 41 of The joint Soviet-Mongolian scientific - Research Geological Expedition. p. 225.

[15] Klyuchevskii, A. V., M. G. Demuyanovich, A. V.Chipizubov, G. Bayar, T. Dugarmaa, V. M. Kochetkov, V. M. Demjanovich, L. Selenge, D. Mönkhöö, V. S. Baskakov and I. Baljinnyam, (2004), Seismic Zoning-In: Complex Geophysical and Seismological Investigation in Mongolia, Ulaanbaatar-Irkutsk, Research Centre of Astronomy and Geophysics of the Mongolian Academy of Sciences, Institute of the Earth's Crust of the Siberian Brench of the Russian Academy of Sciences, Editors Dzhurik, V.I., and T. Dugarmaa ,pp. 171-203.

[16] Levi, K. G., Khromovskikh, V. S., Kochetkov, V. M., Nikolaev, V. V., Semyonov, R. A., Serebrennikov, S. P., Chipizubov, A. V., Demyanovich, M. G., Arzhannikov, S. G., Delyansky, E. A., Smekalin, O. P., Ruzhich, V. V., Buddo, V. Yu., Masalsky, O. K., Potapov, V. A., Berzhinsky, Yu. A. and Radziminovich, Ya. B. (1996). Recent Geodynamics: Seismotectonics, Earthquake Prediction and Seismic Risk (Fundamental and Applied Aspects). The Lithosphere of Central Asia. Nauka, Novosibirsk, pp. 150-182 (in Russian).

[17] Marin, S., Avouac, J.- P., Nicolas, M. and Schlupp, A. A Probabilistic Approach to Seismic Hazard in Metropolitan France, BSSA, Vol 94, N 6, pp. pp. 2137-2163, December 2004.

[18] Odonbaatar, Ch., 2011. "Site Effect Estimation Ulaanbaatar Basin", Thesis at EOST, Strasbourg University, France.

[19] One century of seismicity in Mongolia (1900 - 2000): Coordinators: Dr. Dugarmaa, T., and Dr. Schlupp, A. ; Authors: Adiya M., Ankhtsetseg D., Baasanbat Ts., Bayar, G., Bayarsaikhan, Ch., Erdenezul, D., Möngönsüren, D., Mönkhsaikhan, A., Mönkhöö, D., Narantsetseg, R., Odonbaatar, Ch., Selenge, L., Dr. Tsembel, B., Ölziibat, M., Urtnasan, Kh. and in collaboration with DASE and (RCAG)

[20] Panza, G. F., Romanelli, F., and Vaccari, F., 2001. Seismic Wave Propagation in Laterally Heterogeneous an Elastic Media: Theory and Applications to Seismic Zonation. Advances in Geophysics, Vol. 43, pp. 1-95.

[21] Report, Seismic hazard analysis and microzoning map of Bayankhongor aimag, 2017, IAG MAS.

[22] Ritz, J. F., E. T. Brown, D. L. Bourles, H. Philip, A. Schlupp, G. M. Raisbeck, F. Yiou and E. Enhtövshin., 1995. Slip Rates along Active Faults Estimated with Cosmic Ray Exposure Dates: Application to the Bogd Fault, Gobi-Altay, Mongolia. Geology; v. 23; pp. 1019-1022; 3 figures; 1 table, November.

[23] Ritz, J. F., D. Bourlès, E. T. Brown, S. Carretier, J. Chery, B. Enhtövshin, P. Galsan, R. C. Finkel, T. C. Hanks, K. J. Kendrick, H. Philip, G. Raisbeck, A. Schlupp, D. P. Schwartz and F. Yiou., 2003. Late Pleistocene to Holocene Slip Rates for the Gurvan Bulag Thrust Fault (Gobi-Altay, Mongolia) Estimated with 10Be Dates. Journal of Geophysical Research, vol. 108, N . B3, pp. 2162-2177.

[24] Schlupp, A., "'Neotectonic of Western Mongolia using Field, Seismological and Remote Sensing Data", Laboratoire de Sismologie et de Physique de la Terre, Ecole et Observatoire de Physique du Globe de Strasbourg-Université Louis Pasteur de Strasbourg, PhD, 1 map, 270 pages, in French, 1996. 
[25] Walker, R T., E. Molor E., Fox, M., Bayasgalan, A., 2008., Active Tectonics of an Apparently Aseismic Region: Distributed Active Strike-slip Faulting in the Khangai Mountains of central Mongolia, Geophys. J. Int.

[26] Weichert, D. H., Estimation of the Earthquake Recurrence Parameters for Unequal Observation Periods for Different Magnitudes, Bull. Seism. Soc. Am., 70, pp. 1337-1346, 1980.

[27] Wells, D. L., and K. J. Coppersmith, (1994). New Empirical Relationships Among Magnitude, Rupture Length, Rupture Width, Rupture Area and Surface Displacement, Bull. Seism. Soc. Am. 84, pp. 974-1002.

[28] Yeats, R. S., K. E., Sieh and C. R. Allen, (1997). The Geology of Earthquakes, New York, Oxford University Press.

[29] Yenier, E., et al., 2008. Emperical Relationships for Magnitude and Source-to-site Distance Conversions using Recently Compiled Turkish Strong-ground Motion Database. 